\title{
Financial Transparency and Sources of Hidden Capital in Turkish Banks
}

\author{
Başak Tanyeri
}

Received: 6 November 2006 /Revised: 16 June 2009 / Accepted: 19 June 2009 /

Published online: 30 July 2009

(C) Springer Science + Business Media, LLC 2009

\begin{abstract}
This paper investigates how changes in regulatory and economic environments affect the transparency of banks' financial-statements. Reregulation and a volatile economy make Turkish banks the ideal sample. I disaggregate sources of both hidden and booked capital in Turkish banks traded on the Istanbul Stock Exchange between 1988 and 2006. Hidden capital account for the difference between the accounting and opportunity-cost measures of a firm's net worth. Increases in hidden capital in crisis periods indicate a greater reliance on government-contributed safety-net capital. The increase in hidden capital is more pronounced for large banks. Too-Big-To-Fail policies may explain why large banks are the beneficiaries of government-contributed capital.
\end{abstract}

Keywords Transparency · Financial safety net - Turkish financial crisis

\section{Introduction}

This paper investigates how changes in regulatory and economic environments affect the transparency of financial statements. Financial statements are transparent only when stakeholders can access all relevant information to price financial institutions in a timely fashion (Kane 2004; Vishwanath and Kaufmann 2001). Stakeholders of commercial banks are: shareholders who provide stock-capital, depositors and creditors who contribute debtcapital, borrowers who cultivate relationships with banks to meet financing needs, government regulators who enhance credit-worthiness of banks through implicit and explicit safety-nets, and taxpayers who may end up financing the safety nets.

Incentive conflicts between management, which prepares financial statements, and stakeholders, who rely on statements to accurately value firms, mean that management may misrepresent, conceal, and/or delay information (Jensen and Meckling 1976; Kane 1989; Saunders et al. 1990). Kane (2004) defines financial disinformation as statements that are configured to hinder less-informed stakeholders from discerning the full-information value

B. Tanyeri $(\bowtie)$

Faculty of Business Administration, Bilkent University, 06800 Bilkent, Ankara, Turkey

e-mail: basak@bilkent.edu.tr 
of an enterprise. Management propagates financial disinformation to delay dissemination of unfavorable information and discloses favorable information accurately and promptly. The asymmetry between the timeliness of favorable and unfavorable information means that sudden large downward movements in prices are more likely than upward movements. An economy-wide crisis occurs when financial disinformation is revealed and there are large downward movements in prices.

Stakeholders learn of the depletion in shareholder-contributed capital when financial disinformation is revealed. This revelation necessitates new infusions of shareholder-capital and/or an increased reliance on implicit and explicit forms of government guarantees. The benefits accruing from safety nets cannot be booked whereas capital raised from shareholders can be. Consequently, relying on government-contributed capital instead of raising capital from shareholders would decrease transparency. This paper tracks time-series changes in economic activity to investigate changes in transparency and sources of opaqueness in statements.

The Turkish banking industry provides a fruitful setting in which to investigate how changes in regulatory and economic environments affect the transparency of commercial banks. In the 1980s and 1990s, Turkish regulators passed a series of regulations that transformed how banks conducted business. (Selçuk and Ertuğrul 2001; Alper and Öniş 2003; Damar 2004; Öniş and Bakır 2007). Turkish economy also proved volatile in the same period (Kibritçioğlu 2001).

This paper sheds light on how the current subprime-mortgage crisis affects emergingmarket countries. Emerging-market countries do not have as developed mortgage markets, and their banks do not use securitization as often as banks in the US or Western Europe. As such, securitization and mortgage-backed securities should not pose the same problems in emerging markets as they do in US and developed markets. However, greater integration in the world economy, the global recession and the credit crunch is affecting emerging-market countries that need to finance their growth. The sub-prime mortgage crisis has caught banks and borrowers of emerging markets with short positions in foreign currencies and a sizable need to roll-over. Net private flows to emerging economies are forecasted to be $\$ 165$ billion USD in 2009 down from $\$ 929$ billion in 2007 (Institute of International Finance 2009). The stage for a global crisis spilling over to emerging-market economies is set. How well regulators meet the demands set forth by the crisis remains to be seen. Banks in emerging markets have large foreign currency positions and have gone through similar deregulatory phases as Turkish banks did. The experience of Turkish banks and regulators in the 1994 and 2001 crises may enhance our understanding of how the current crisis affects emerging markets.

I adapt Kane and Ünal's (1990) statistical market-value accounting model (SMVAM) to disaggregate sources of capital in Turkish banks traded on the Istanbul Stock Exchange (ISE) using data from 1988 to 2006. SMVAM uses regression analysis to partition the market value of a firm's stock into two components: booked capital-reserves and unbooked (or hidden) capital. Hidden capital accounts for the difference between the accounting and market-value measures of a firm's net worth. Hidden capital is divided into two parts. The first part consists of the values that are unbooked but which might be registered through asset sales and subsequent write-downs in a historical-cost balance sheet using Generally Accepted Accounting Principles (GAAP). The second part comprises the values that are unbooked and which GAAP deems to be intangible off-balance-sheet items.

Hidden capital proves to be a significant component of net worth. Furthermore, hidden capital is significantly larger in crisis periods than it is in non-crisis periods. Heavier reliance on government-contributed capital prior and during periods of crisis may explain 
the significant surges in hidden capital. The largest four banks in the sample, which account for $48 \%$ of Turkish banking assets ${ }^{1}$, are more likely to benefit from implicit government guarantees than are the small banks. A policy of Too-Big-To-Fail, where the government is expected to not let large banks fail, increases shareholder wealth by decreasing financing costs (O'Hara and Shaw 1990). I conjecture that the four large banks were deemed TooBig-To-Fail and enjoyed the benefits from implicit and explicit safety nets.

During the sample period, Turkish banks categorized foreign-currency related derivative transactions as off-balance-sheet transactions. Banks had the leeway to engage in these transactions without having to set aside shareholder-contributed capital. Short positions in foreign currencies attained using derivative products coupled with devaluation in the Turkish lira in crisis periods, such as in 1994 and 2001, might have generated a need for infusions of capital. Banks may raise capital from shareholders, or, in the form of heavier reliance on implicit and explicit safety nets from the government.

Results indicate a heavier reliance on government-provided capital in crisis periods. Furthermore, I find no significant increase in shareholder-contributed capital in crisis periods relative to non-crisis periods. Regulators instituted full deposit-insurance coverage following the crises in 1994 and 2001. The regulatory choice to increase governmentprovided guarantees points to a need for and a realization of increased reliance on government-provided capital.

The Turkish experience in the crises of 1994 and 2001 indicates that banks rely on government-contributed capital more than they do on shareholder-contributed capital. One immediate response to crisis is to introduce full-deposit insurance to restore investor confidence. However, full-deposit insurance distorts the risk-taking incentives of banks and introduces moral hazard problems. Banks can increase the value derived from deposit insurance by increasing asset volatility (Merton 1977). Grossman (1992) shows how financial institutions covered by deposit insurance operating under relatively more permissive regulatory environments tend to carry out riskier lending than their more tightly regulated counterparts do. The introduction of blanket guarantees in the 1994 and 2001 crises indicates that Turkish regulators did not establish risk-sensitive, incentive-compatible safety nets. The cost of providing capital to unhealthy banks through implicit and explicit guarantees was ultimately borne by healthy banks and the Turkish taxpayer.

Reliance on government guarantees and Too-Big-to-Fail policies make financial statements opaque. Opaqueness in financial statements impairs the ability of regulators and taxpayers to distinguish between troubled and healthy banks. Kane (1997) explains how transparency is crucial in controlling incentive conflicts between regulators, regulated institutions, and taxpayers. Regulated institutions have incentives to hide adverse information from regulators and the general public. Regulators, as self-interested agents that serve society and private sector interests, are often the targets of influence peddling from regulated institutions. This is why transparency of financial statements is vital for regulators to monitor regulated institutions and for taxpayers to evaluate the performance of regulators.

The plan for the remainder of the paper is as follows. Section 1 develops the research design. Section 2 reports the results of the tests of hypotheses. Finally, Section 3 concludes the paper.

\footnotetext{
${ }^{1}$ The figure is as of 2006 and the data is available from The Banks Association of Turkey.
} 


\section{Research design}

\subsection{Hypotheses and design of tests}

I use SMVAM to operationalize transparency. Transparency of financial statements means that stakeholders (depositors, creditors, investors, regulators, taxpayers, borrowers, and bankers) can rely on statements to judge the health of banks. In a perfectly transparent world, market value (the "true" economic value of the bank) would exactly coincide with book value. A stakeholder would work out the value of any bank by looking into its books.

SMVAM $^{2}$ develops separate estimates for the bookable and unbookable components of the market value of a banking firm. Market value of net worth (MV) is the product of share price and the number of shares outstanding. Market value can also be thought of as the sum of the market value of bookable and unbookable assets minus the sum of market value of bookable and unbookable liabilities.

Banks carry bookable assets and liabilities at historical costs; therefore, current values cannot be directly observed. Assuming that investors estimate the market value of bookable equity by using appropriate mark-up (or markdown in the cases of downward adjustment) ratios $\left(\mathrm{k}_{\mathrm{a}}\right.$ and $\mathrm{k}_{1}$ respectively) to the accounting values, the below equation is obtained:

$$
\mathrm{MV}_{\mathrm{it}}=\mathrm{U}+\mathrm{k}_{\mathrm{a}} * \mathrm{~A}_{\mathrm{it}}+\mathrm{k}_{1} * \mathrm{~L}_{\mathrm{it}}+\mathrm{e}_{\mathrm{it}},
$$

where,

$\mathrm{A}_{\mathrm{u}}:$ Unbookable assets,

$\mathrm{U}=\mathrm{A}_{\mathrm{u}}-\mathrm{L}_{\mathrm{u}}$ : Hidden capital,

$\mathrm{L}_{\mathrm{it}}$ : Bookable liabilities of bank $\mathrm{i}$ at time $\mathrm{t}$,

$\mathrm{k}_{1}$ : Mark-up ratio for bookable liabilities,
$\mathrm{L}_{\mathrm{u}:}$ Unbookable liabilities,

$\mathrm{A}_{\mathrm{it}}$ : Bookable assets of bank $\mathrm{i}$ at time $\mathrm{t}$, $\mathrm{k}_{\mathrm{a}}$ : Mark-up ratio for bookable assets, $\mathrm{e}_{\mathrm{it}}$ : Error term of bank $\mathrm{i}$ at time $\mathrm{t}$.

Banks report some transactions that may affect net worth in footnotes that accompany the financial statements. These off-balance-sheet transactions include loan commitments, standby letters of credit, and foreign-currency-related and interest-rate-related derivative contracts. The Turkish lira steadily depreciated against all foreign currencies as a result of persistent inflation in the last two decades. The volatility in the exchange rate has also been high. Any bank with large short-positions or long-positions in foreign currencies faced foreign-exchange risk. This is why I introduce foreign-currency-related derivative contracts $^{3}$ into Eq. (1).

$$
\mathrm{MV}_{\mathrm{it}}=\mathrm{U}+\mathrm{k}_{\mathrm{a}} * \mathrm{~A}_{\mathrm{it}}+\mathrm{k}_{1} * \mathrm{~L}_{\mathrm{it}}+\mathrm{k}_{\mathrm{FX}} * \mathrm{FX}_{\mathrm{it}}+\mathrm{e}_{\mathrm{it}},
$$

where $\mathrm{FX}_{\mathrm{it}}$ is foreign-currency-related derivative transactions and $\mathrm{k}_{\mathrm{FX}}$ is the mark-up ratio investors apply to these transactions.

Cross-sectional differences in bank size and time-series differences in economic activity may affect estimates of SMVAM. First, bank size may affect the competitive environment and how regulatory authorities treat banks (O’Hara and Shaw 1990; DeYoung et al. 2004;

\footnotetext{
${ }^{2}$ Kane and Ünal (1990), Kane, Ünal, and Demirgüç-Kunt 1991, and Kane and Wilson 2002 apply SMVAM to disaggregate the sources of capital for a sample: of US banks from 1975-1985, of Japanese banks from 1975-1989, and of US and Canadian banks from 1893-1992, respectively.

${ }^{3}$ Foreign-currency related derivative contracts include foreign-exchange forward contracts, swap contracts, foreign exchange and interest-rate option contracts, and interest-rate futures contracts.
} 
Berger et al. 2004). As a result, SMVAM estimates of markup ratios and hidden capital may differ for small and large banks. Second, bank management has incentives to conceal and delay dissemination of adverse information. In financial crisis when accumulated adverse information is revealed, investors may value bank assets differently (Kane 2001, 2004). This is why SMVAM estimates in crisis periods may differ from estimates in non-crisis periods.

I use the seemingly unrelated regressions (SUR) framework ${ }^{4}$ to estimate SMVAM for large and small banks. Market capitalizations of small and large banks are regressed on their book values of assets, liabilities and foreign-exchange-related derivative transactions. Interaction terms between the variables and a crisis indicator control for differences in estimates in normal times and times of crisis. I estimate the following system of equations using Feasible Generalized Least Squares (FGLS):

$$
\begin{aligned}
& \mathrm{MV}_{\mathrm{S}, \text { it }}=\mathrm{U}_{\mathrm{S}}+\mathrm{k}_{\mathrm{a}, \mathrm{S}} * \mathrm{~A}_{\mathrm{S}, \mathrm{it}}+\mathrm{k}_{\mathrm{l}, \mathrm{S}} * \mathrm{~L}_{\mathrm{S}, \text { it }}+\mathrm{k}_{\mathrm{FX}, \mathrm{S}} * \mathrm{FX}_{\mathrm{S}, \text { it }}+\mathrm{U}_{\mathrm{S}, \text { crisis }} * \mathrm{I}_{\text {crisis }}+\mathrm{k}_{\mathrm{a}, \mathrm{S}, \text { crisis }} * \\
& \mathrm{~A}_{\mathrm{S}, \mathrm{it}} * \mathrm{I}_{\text {crisis }}+\mathrm{k}_{\mathrm{l}, \mathrm{S}, \text { crisis }} * \mathrm{~L}_{\mathrm{S}, \mathrm{it}} * \mathrm{I}_{\text {crisis }}+\mathrm{k}_{\mathrm{FX}, \mathrm{S}, \text { crisis }} * \mathrm{FX}_{\mathrm{S}, \mathrm{it}} * \mathrm{I}_{\text {crisis }}+\mathrm{e}_{\mathrm{S}, \mathrm{it}}, \\
& \mathrm{MV}_{\mathrm{L}, \mathrm{it}}=\mathrm{U}_{\mathrm{L}}+\mathrm{k}_{\mathrm{a}, \mathrm{L}} * \mathrm{~A}_{\mathrm{L}, \mathrm{it}}+\mathrm{k}_{\mathrm{l}, \mathrm{L}} * \mathrm{~L}_{\mathrm{L}, \mathrm{it}}+\mathrm{k}_{\mathrm{FX}, \mathrm{L}} * \mathrm{FX}_{\mathrm{L}, \mathrm{it}}+\mathrm{U}_{\mathrm{L}, \text { crisis }} *{ }_{\text {crisis }}+\mathrm{k}_{\mathrm{a}, \mathrm{L}, \text { crisis }} \\
& { }^{*} \mathrm{~A}_{\mathrm{L}, \mathrm{it}} * \mathrm{I}_{\text {crisis }}+\mathrm{k}_{\mathrm{l}, \mathrm{L}, \text { crisis }} * \mathrm{~L}_{\mathrm{L}, \mathrm{it}} * \mathrm{I}_{\text {crisis }}+\mathrm{k}_{\mathrm{FX}, \mathrm{L}, \text { crisis }} * \mathrm{FX}_{\mathrm{L}, \mathrm{it}} * \mathrm{I}_{\text {crisis }}+\mathrm{e}_{\mathrm{L}, \mathrm{it}}
\end{aligned}
$$

$\mathrm{I}_{\text {crisis }}$ is an indicator for crisis periods. The subscripts " $\mathrm{S}$ ", " $\mathrm{L}$ ", "S, crisis", and " $\mathrm{L}$, crisis" stand for small banks, large banks, small banks in crisis periods, and large banks in crisis periods, respectively.

Hidden capital would not exist in a perfectly transparent world. In a sense, the extent to which unbooked equity $(\mathrm{U})$ deviates from zero and the mark-up ratios $(\mathrm{k})$ deviate from unity is an inverse measure of transparency. I expect some opaqueness in financial statements due to the leeway that GAAP grants managers in how they report bank activities. I test the following hypothesis of transparency for each group of banks:

Hypothesis 1 Financial statements are transparent.

$$
\begin{aligned}
& \left(\mathrm{U}_{\mathrm{n}}=0 \text { and } \mathrm{k}_{\mathrm{a}, \mathrm{n}}=1 \text { and } \mathrm{k}_{\mathrm{l}, \mathrm{n}}=-1, \mathrm{n}=\mathrm{S}, \mathrm{L}\right. \text { in normal times } \\
& \left.\mathrm{U}_{\mathrm{n}}+\mathrm{U}_{\mathrm{n}, \text { crisis }}=0 \text { and } \mathrm{k}_{\mathrm{a}, \mathrm{n}}+\mathrm{k}_{\mathrm{a}, \mathrm{n}, \text { crisis }}=1 \text { and } \mathrm{k}_{1, \mathrm{n}}+\mathrm{k}_{1, \mathrm{n}, \text { crisis }}=-1, \text { in times of crisis }\right)
\end{aligned}
$$

Next, I test the hypotheses that cross-sectional differences in bank size and time-series differences in economic activity may affect SMVAM estimates. First, I test whether banks raise capital either from shareholders or from the government in crisis periods. In times of financial crisis, managers cannot avoid/delay dissemination of adverse information. Revelation of adverse information lowers asset prices. Consequently, banks need to raise capital either from shareholders or from government regulators.

Hypothesis 2 Banks raise capital neither from shareholders nor from government regulators in crisis periods.

Second, I test the hypothesis that large and small banks operate and report their operations in inherently different ways. If the data confirms the hypothesis, SMVAM estimates of large and small banks should prove different. Even if small and large banks operate and report their operations in similar ways, Too-Big-To-Fail policies might cause a

\footnotetext{
${ }^{4}$ In designing the SUR framework, I benefited from the methodology of Ünal et al. (1993) who develop a SUR model to measure market reactions to announcements of the Brady plan and the Mexican-debt reduction.
} 
difference in how regulators treat small and large banks. If regulatory authorities treat banks of different sizes in dissimilar ways, SMVAM estimates of small and large banks would be different.

Hypothesis 3 SMVAM estimates of small banks and large banks are equal.

$$
\begin{aligned}
\left(\mathrm{U}_{\mathrm{L}}\right. & =\mathrm{U}_{\mathrm{S}} \text { and } \mathrm{k}_{\mathrm{a}, \mathrm{L}}=\mathrm{k}_{\mathrm{a}, \mathrm{S}} \text { and } \mathrm{k}_{1, \mathrm{~L}}=\mathrm{k}_{1, \mathrm{~S}} \text { in normal times } \\
\mathrm{U}_{\mathrm{L}} & +\mathrm{U}_{\mathrm{L}, \text { crisis }}=\mathrm{U}_{\mathrm{s}}+\mathrm{U}_{\mathrm{S}, \text { crisis }} \text { and } \mathrm{k}_{\mathrm{a}, \mathrm{L}}+\mathrm{k}_{\mathrm{a}, \mathrm{L}, \text { crisis }}=\mathrm{k}_{\mathrm{a}, \mathrm{S}}+\mathrm{k}_{\mathrm{a}, \mathrm{S}, \text { crisis }} \text { and } \mathrm{k}_{\mathrm{l}, \mathrm{L}} \\
& \left.+\mathrm{k}_{\mathrm{i}, \mathrm{L}, \text { crisis }}=\mathrm{k}_{\mathrm{l}, \mathrm{S}}+\mathrm{k}_{\mathrm{L}, \mathrm{L}, \text { cirsis }} \text { in times of crisis }\right)
\end{aligned}
$$

\subsection{The choice of Turkish banks}

Reregulation and a volatile economy make Turkish banks ideal to investigate how changes in regulation and economic environment affect transparency of financial institutions. I first summarize the regulatory changes that alter the operation of Turkish banks in the sample period. I then discuss the economic environment.

In the early 1980s, financial liberalization caused major structural changes in the Turkish economy ${ }^{5}$. Before financial liberalization, Turkey followed a strict, domestic-marketoriented, high-tariff-protected development strategy. In accordance with this strategy, the government determined interest rates. Regulation imposed high entry and exit costs to the banking sector. Development plans defined the objective of financial institutions as raising capital needed for investment in "high-priority" industries. Starting in 1980, the administration adopted a new development strategy based on "free market" notions of competition. As a result of financial liberalization, banks were able to set interest rates on deposits they attracted and on the credit they supplied.

The new political economy brought in by financial liberalization created the need for a deposit insurance system. Tasarruf Mevduatı Sigorta Fonu (TMSF or Savings Deposit Insurance Fund), which laid the foundation for the current deposit insurance system, was established in 1983. TMSF guaranteed up to three million TL (approximately 57,000 in 2006 YTL or 40,000 in 2006 USD $^{6}$ ) of time deposits. Subsequent laws revised the fund's organization, insurance coverage, premiums level and structure of the premiums system. Following the economic crisis of April 1994, the board of government ministers passed a law that mandated unlimited insurance on all TL and foreign-currency deposits (effective 5 April 1994). Regulators limited insurance coverage to fifty billion TL (approximately 193,000 in 2006 YTL or 137,000 in 2006 USD) as of 1 June 2000. Limited insurance coverage was short-lived. In the wake of the 2000 crisis, regulators reinstated full insurance coverage on 15 January 2001. For 10 years starting in 1994, except for six months in 2000, Turkish depositors enjoyed government guarantees on all their deposits. Effective July 5 2004, insurance coverage was limited to fifty billion TL (approximately 62,000 in 2006 YTL or 44,000 in 2006 USD) and remains limited to 50 thousand new TL to this day ${ }^{7}$.

\footnotetext{
${ }^{5}$ Selçuk and Ertuğrul (2001), Damar (2004), and The Banks Association of Turkey (1998) describe and discuss the financial liberalization program in detail.

${ }^{6}$ Turkish currency prior to January 12006 is Turkish lira (TL). Turkey deleted six zeros in the Turkish lira as of January 12005 and the new currency is labeled Yeni Turkish lira (YTL). We use World Bank (available at http://devdata.worldbank.org/dataonline) data series on consumer price index (CPI) and official exchange rate from Central Bank of Turkey to deflate to 2006 YTL and convert to US dollars.

${ }^{7}$ Alparslan et. al. (2000) and The Banks Association of Turkey (2001) discuss the evolution of the Saving Deposit Insurance Fund.
} 
Starting in the late eighties and continuing through the nineties, chronically high inflation and government borrowing changed bank incentives. First, high government borrowing meant that banks lent as intensively to the government as to firms and individuals. Investments in liquid assets proved as important as investments in loans throughout the 1990s. Second, faced with high inflation, depositors began to favor foreigncurrency deposits. At 1993 year-end, the ratio of deposits and borrowings to assets proved to be $77 \%$ for banks with no government ownership. Foreign-currency deposits and borrowings constituted 66 and $91 \%$ of all deposits and borrowings, respectively. Banks financed their investments in TL-denominated government-debt and loans through deposits and borrowings mainly denominated in foreign currencies ${ }^{8}$.

The strategy of investing in TL assets financed by foreign-currency deposits and borrowing would expose banks to foreign-exchange risk. Foreign-currency denominated liabilities proved larger than assets throughout the 1990s and, so far, the 2000s. In the absence of proper hedging, any depreciation in the Turkish lira would hurt bank equity. In the 5 days following April 41994 TL devalued by 48\% against the USD ${ }^{9}$. Three banks (TYT bank, Marmarabank and Impexbank) declared bankruptcy and were closed by the TMSF on 11 April 1994.

The Turkish government instigated full insurance coverage to reinstate confidence in the banking system. Full insurance coverage and International Monetary Fund (IMF) aid forestalled troubles in the short run. However, Müslümov (2005), Soral et al. (2006) Önder and Özyıldırım (2008) study how full-deposit insurance may have contributed to excessive risk taking and fraud. Müslümov (2005) finds that banks that are more likely to be subject to moral hazard show significant increases in foreign-exchange risk and deterioration in capital adequacy. Önder and Özyıldırım (2008) find that despite the presence of generous deposit insurance, borrowers and depositors punished risky banks. Soral et al. (2006) document how full-deposit insurance might have contributed to the looting of Esbank.

Investments in TL-denominated assets financed by foreign-currency-denominated liabilities remained unchecked following the 1994 crisis. Moral hazard problems caused by full deposit-insurance coupled with the vulnerability of banks to depreciation in the TL may have set up the stage for the problems banks faced after 1994.

East Asian currency crisis started in Thailand in July 1997 (TL depreciated by 7.52\% against the USD in this month) and spread to the majority of East Asian countries. The East Asian crisis continued to unfold in 1998 and may have contributed to the Russian crisis which started in August 1998 (the TL depreciated by 2.71\% in this month) (Berg 1999; Kane 2000). As a developing country and a significant trade partner of Russia, Turkey experienced repercussions in its economy and banking industry. In addition to the contagion effect of the East Asian and Russian crises, a natural catastrophe, the İzmit earthquake in August 1999, also significantly affected the banking industry. İzmit is located in the Turkish industrial heartland. The earthquake caused devastating losses to human life and real assets. Banks and insurance companies with investments and customers in this area faced significant losses.

\footnotetext{
${ }^{8}$ Numbers based on the aggregate data on banks provided by the The Banks Association of Turkey (http:// www.tbb.org.tr/bbts/default.aspx).

${ }^{9}$ Devaluation in TL calculated using Turkish Central Bank bid prices (http://evds.tcmb.gov.tr/cgi-bin/ famecgi?cgi=\$ozetweb\&DIL=TR\&ARAVERIGRUP=bie_dkdovizgn.db).
} 
Foreign-exchange risk combined with above mentioned factors may have contributed to the closure of eight banks by the TMSF from November 1997 to December 1999. Two of these eight banks, Esbank and Yaşarbank are in the sample. In the latter part of 1999, the newly elected Turkish government set out on a course of IMF-aided economic program focusing on decreasing inflation. This program called for strict controls on the economy as a whole. Special emphasis was placed on reforming the banking system. Laws requiring greater transparency were enacted.

The IMF program could not prevent a deepening of the financial crisis in late 2000. The inability of the largest Turkish banks to cover their over-night positions in the Repo and Reverse-Repo markets triggered another crisis (Danielsson and Saltoğlu 2003). On February 19 2001, spurred by political uncertainty, matters worsened ${ }^{10}$. In the five trading days following the $19^{\text {th }}$, the TL devalued by $40 \%$ against the USD and the interbank interest rate hit highs of $6,200 \%$. TMSF closed down eleven banks from October 2000 to November 2001. Of these eleven banks, Demirbank and Toprakbank are in the sample.

\subsection{Sampling frame}

Statistical Market Value Accounting Model requires the collection of market capitalization $^{11}$, which is provided by Datastream for all the Turkish banks listed on ISE on a yearly or quarterly basis. I exclude banks in which the government has an ownership stake since government-owned banks have different incentives than non-government-owned banks ${ }^{12}$. Table 1 catalogs listing and delisting dates for the sample banks. The first commercial bank to list on the ISE was İş Bankası on January $4,1988^{13}$, and the last one was Denizbank on September 30, 2004. Table 1 also provides data on events that significantly alter the ownership structure of sample banks. Waves of bankruptcies and mergers mark the sample period. Number of banks in the sample ranges from two to thirteen. Merger-announcement dates are pulled together from files of firm news provided by $\mathrm{ISE}^{14}$. Of the banks in the sample, the TMSF closed Marbank following the crisis in 1994, closed Esbank and Yaşarbank following the turbulence in 1998, and closed Toprakbank and Demirbank after the 2001 crisis. All but two of the surviving sample banks received acquisitions bids in 2005 and 2006. As shown in Table 1, all bidders except one were non-Turkish banks.

Türkiye Bankacilar Birliği (The Banks Association of Turkey or TBB) provides financial statements on an annual basis until 1996 and on a quarterly basis from 1997. I compile a dataset containing the book value of assets and liabilities from annual and quarterly balance sheets. I also collect data on off-balance-sheet items reported in the footnotes. The sample period is a time of high inflation, which ranged from $74 \%$ in 1988 to

\footnotetext{
${ }^{10}$ Press articles cite a public argument between the president and the prime minister as the culprit for political uncertainty and catalyst for the crisis (Milliyet 2001).

${ }_{11}$ Datastream defines market capitalization as common shares outstanding multiplied by share price.

12 None of the sample banks is an Islamic financial institution since no Islamic bank is listed on the ISE. Islamic financial institutions entered the Turkish financial services industry in 1985 and account for one to three percent of all deposits from 1991 to 2001. Interested readers may refer to Jang (2005) for the evolution of Islamic banking in Turkey.

${ }^{13}$ İs Bankası lists three different shares (type $\mathrm{A}, \mathrm{B}$, and $\mathrm{C}$ ). $\mathrm{A}, \mathrm{B}$, and $\mathrm{C}$ shares command common voting and control rights. A and B shares receive preferential treatment in dividend payouts (http://www.isbank. com.tr/yatirimci/yi-imtiyazli.html). We sum up the market capitalization for the three types of shares listed on ISE to calculate market capitalization of İș Bankası. İș Bankası type A shares were listed on the ISE on February 5,1988, type B shares on January 4, 1988, and type C shares on August 19, 1991.

${ }^{14}$ Files containing firm news can be accessed at http://www.imkb.gov.tr/sirkethaberleri.htm.
} 
Table 1 List of sample banks. Datastream provides listing and delisting dates of sample banks. Mergerrelated information is pulled from firm-news archives of the ISE

\begin{tabular}{|c|c|c|c|c|c|c|}
\hline Bank name & $\begin{array}{l}\text { Listing } \\
\text { date }\end{array}$ & $\begin{array}{l}\text { Delisting } \\
\text { date }\end{array}$ & $\begin{array}{l}\text { Merger } \\
\text { announcement } \\
\text { date }\end{array}$ & $\begin{array}{l}\text { Merger } \\
\text { status }\end{array}$ & Merger partner & $\begin{array}{l}\text { Ownership } \\
\text { sought }\end{array}$ \\
\hline Akbank & $7 / 26 / 1990$ & & $10 / 17 / 2006$ & Completed & $\begin{array}{c}\text { Citibank Overseas } \\
\text { Invesment } \\
\text { Corporation }\end{array}$ & $20 \%$ \\
\hline \multirow[t]{3}{*}{ Alternatifbank } & $7 / 18 / 1995$ & & $3 / 20 / 1996$ & Completed & Anadolu Group & $80 \%$ \\
\hline & $7 / 18 / 1995$ & & $4 / 2 / 2002$ & Withdrawn & $\begin{array}{c}\text { Credit Agricole } \\
\text { Indosuez }\end{array}$ & $100 \%$ \\
\hline & $7 / 18 / 1995$ & & $11 / 15 / 2006$ & Completed & Alpha Bank A.E. & $50 \%$ \\
\hline Demirbank & $7 / 11 / 1990$ & $9 / 27 / 2001$ & & & & \\
\hline Denizbank & $9 / 30 / 2004$ & & $5 / 31 / 2006$ & Completed & $\begin{array}{c}\text { Dexia } \\
\text { Participation } \\
\text { Belgique S.A }\end{array}$ & $75 \%$ \\
\hline Esbank & $6 / 10 / 1991$ & $12 / 22 / 1999$ & & & & \\
\hline Finansbank & $2 / 2 / 1990$ & & $4 / 3 / 2006$ & Completed & $\begin{array}{c}\text { National Bank } \\
\text { of Greece }\end{array}$ & $46 \%$ \\
\hline Dișbank & $9 / 13 / 1990$ & & $4 / 12 / 2005$ & & Fortis Bank & $89.34 \%$ \\
\hline $\begin{array}{l}\text { Garanti } \\
\text { Bankası }\end{array}$ & $6 / 6 / 1990$ & & $8 / 18 / 2005$ & Completed & $\begin{array}{c}\text { General Electric } \\
\text { Group }\end{array}$ & $25.50 \%$ \\
\hline İș Bankası & $2 / 5 / 1988$ & & & & & \\
\hline Marbank & $3 / 31 / 1989$ & 6/30/1994 & & & & \\
\hline Şekerbank & 4/11/1997 & & $6 / 22 / 2006$ & Completed & $\begin{array}{l}\text { Bank Turan } \\
\text { Alem Group }\end{array}$ & $33.97 \%$ \\
\hline TEB & $2 / 18 / 2000$ & & $6 / 28 / 2004$ & Completed & BNP Paribas & $42.13 \%$ \\
\hline Tekstilbank & $5 / 23 / 1990$ & & & & & \\
\hline Toprakbank & $6 / 25 / 1998$ & $11 / 30 / 2001$ & & & & \\
\hline Yapı Kredi Bankası & $1 / 8 / 1988$ & & $1 / 7 / 2005$ & Completed & Koçbank & $57.43 \%$ \\
\hline Yașarbank & 9/5/1990 & $12 / 21 / 1999$ & & & & \\
\hline
\end{tabular}

$9 \%$ in 2006 , with a low of $8 \%$ and a high of a $106 \%$. As such, I deflate all data items using the Consumer Price Index (CPI) provided by World Bank. All items are in December 2006 million YTL.

Table 2 provides descriptive statistics on market-capitalization, book values of assets and liabilities, and foreign-exchange-related off-balance-sheet items ${ }^{15}$. Four banks - namely, İș Bankası, Akbank, Garanti Bankası and Yapı Kredi Bankası - prove the largest in terms of market capitalization and asset size. The average market capitalization for the largest four banks is 7,909 million YTL whereas it is 688 million YTL for the remaining banks. In the analysis, SVMAM estimates of these large four banks will be allowed to differ from the estimates of small banks.

I adopt the metric Kibritçioğlu (2001) develops to identify crisis periods in the Turkish economy. The author constructs an index of macroeconomic crisis using indices of real

\footnotetext{
${ }^{15}$ Numbers in YTL. For readers interested in converting to USD, Turkish Central Bank exchange rate on December 292006 was 1.41 YTL per USD.
} 
Table 2 Descriptive statistics for sample banks. Panel A and B list mean market capitalization, book value of assets and liabilities, and off-balance-sheet foreign-exchange-related items of small and large banks, respectively. Values are in December-2006 million YTL

\begin{tabular}{|c|c|c|c|c|}
\hline Bank name & $\begin{array}{l}\text { Market } \\
\text { capitalization }\end{array}$ & Assets & Liabilities & $\begin{array}{l}\text { Off-balance- } \\
\text { sheet-FX }\end{array}$ \\
\hline \multicolumn{5}{|l|}{ Panel A - Large Banks } \\
\hline İș Bankası & 12,256 & 34,349 & 29,632 & 2,967 \\
\hline Akbank & 9,901 & 29,540 & 25,830 & 5,846 \\
\hline Garanti Bankası & 4,810 & 25,633 & 23,330 & 9,108 \\
\hline Yapı Kredi Bankası & 4,668 & 23,167 & 20,631 & 4,488 \\
\hline \multicolumn{5}{|l|}{ Panel B - Small Banks } \\
\hline Denizbank & 2,910 & 12,226 & 11,057 & 6,196 \\
\hline Finansbank & 1,516 & 8,926 & 8,204 & 9,448 \\
\hline Dișbank & 960 & 5,069 & 4,490 & 2,699 \\
\hline Demirbank & 884 & 5,349 & 4,987 & 4,371 \\
\hline TEB & 549 & 5,474 & 5,068 & 2,407 \\
\hline Esbank & 272 & 3,732 & 3,439 & 1,241 \\
\hline Șekerbank & 257 & 3,015 & 2,801 & 355 \\
\hline Toprakbank & 242 & 4,945 & 4,729 & 1,860 \\
\hline Alternatifbank & 215 & 1,670 & 1,557 & 2,623 \\
\hline Yaşarbank & 209 & 3,576 & 3,376 & 7,061 \\
\hline Tekstilbank & 165 & 1,562 & 1,431 & 1,999 \\
\hline Marbank & 77 & 1,114 & 1,072 & NA \\
\hline
\end{tabular}

industrial production, monthly inflation, and exchange rate. I generate an indicator of macroeconomic crisis that takes on the value one in the years 1988, 1989, 1991, 1994, 1999, and 2001, and zero in all other years.

\section{Results}

I estimate the system of equations represented in Eq. (3) using FGLS. I allow for heteroscedasticity in variances of small and large banks ${ }^{16}$. Table 3 reports the results of this regression. Observations in the sample are annual until the end of 1996 and are quarterly after 1996. This is why I estimate the system of equations using the full sample (the first column of Table 3 reports results), the subsample from 1997 to 2006 (second column), the subsample from 1988 to 1996 (third column), and the subsample that only covers end-ofyear data from 1988 to 2006 (fourth column).

The difference in annual versus quarterly reporting splits the sample into two subsamples of nine and 10 years, respectively. There are 445 quarterly observations in the subsample covering 1997 to 2006 and 62 annual observations in the subsample covering 1988 to 1996. Furthermore, there are 160 large-bank and 285 small-bank observations in the subsample

\footnotetext{
${ }^{16}$ In the SUR framework, contemporaneous correlation across groups is possible if the groups have equal number of observations and share a common identifier (such as time or firm identity). In our sample, the groups are unbalanced in their number of observations. This is why we cannot allow for contemporaneous correlation across groups (Baum, 2006; STATA Press, 2005; Wooldridge, 2002).
} 
Table 3 Estimates of statistical market value accounting model for small and large banks with controls for crisis periods. The following system of equations is estimated using Feasible Generalized Least Squares (FGLS): $\mathrm{MV}_{\mathrm{k}, \mathrm{it}}=\mathrm{U}_{\mathrm{k}}+\mathrm{k}_{\mathrm{a}, \mathrm{k}} * \mathrm{~A}_{\mathrm{k}, \mathrm{it}}+\mathrm{k}_{\mathrm{l}, \mathrm{k}} * \mathrm{~L}_{\mathrm{k}, \mathrm{it}}+\mathrm{k}_{\mathrm{FX}, \mathrm{k}} * \mathrm{FX}_{\mathrm{k}, \mathrm{it}}+\mathrm{U}_{\mathrm{k}, \text { crisis }}+\mathrm{k}_{\mathrm{a}, \mathrm{k} \text {, crisis }} * \mathrm{~A}_{\mathrm{k}, \mathrm{it}} * \mathrm{I}_{\text {crisis }}+\mathrm{k}_{\mathrm{l}, \mathrm{k}, \text { crisis }} *$ $\mathrm{L}_{\mathrm{k}, \mathrm{it}} * \mathrm{I}_{\text {crisis }}+\mathrm{k}_{\mathrm{FX}, \mathrm{k} \text {, crisis }} * \mathrm{FX}_{\mathrm{k}, \mathrm{it}} * \mathrm{I}_{\text {crisis }}+\mathrm{e}_{\mathrm{k}, \mathrm{it}}$, where $\mathrm{k}$ : $\mathrm{L}, \mathrm{S}$. The subscripts "L" and " $\mathrm{S}$ " stand for large and small banks. MV is market value of net worth. A and L are book values of assets and liabilities. FX is book value of off-balance-sheet foreign-currency related derivative contracts. $U$ stands for hidden capital; $k_{a}, k_{1}$ and $\mathrm{k}_{\mathrm{fX}}$ stand for mark-up ratios of assets, liabilities and FX, respectively. $\mathrm{I}_{\text {crisis }}$ is an indicator for crisis years. Values are in December-2006 million YTL. The first column reports results estimated on the full sample; the second column on the subsample from 1997 to 2006; the third column on the subsample from 1988 to 1996 ; and the fourth column on the subsample that covers end-of-year data from 1988 to 2006. Absolute values of standard errors are in brackets. Significance levels are shown as *, ** and ***, representing $10 \%, 5 \%$, and $1 \%$ significance

\begin{tabular}{|c|c|c|c|c|}
\hline & Full sample & 1997-2006 & 1988-1996 & Annual Data \\
\hline \multirow[t]{2}{*}{$\mathbf{U}_{\mathrm{S}}$} & $-304.71 * * *$ & $-360.22 * * *$ & 91.08 & -171.17 \\
\hline & [69.59] & [79.15] & [68.20] & [114.78] \\
\hline \multirow[t]{2}{*}{$\mathbf{k}_{\mathrm{a}, \mathrm{s}}$} & $1.32 * * *$ & $1.40 * * *$ & $-1.18^{*}$ & $1.80 * * *$ \\
\hline & {$[0.31]$} & {$[0.33]$} & {$[0.65]$} & {$[0.56]$} \\
\hline \multirow[t]{2}{*}{$\mathbf{k}_{\mathbf{l}, \mathbf{s}}$} & $-1.24 * * *$ & $-1.32 * * *$ & $1.38 * *$ & $-1.78 * * *$ \\
\hline & {$[0.34]$} & {$[0.37]$} & {$[0.69]$} & {$[0.62]$} \\
\hline \multirow[t]{2}{*}{$\mathbf{k}_{\mathbf{F X}, \mathbf{S}}$} & $0.05 * * *$ & $0.05^{* * *}$ & -0.04 & $0.05 *$ \\
\hline & {$[0.02]$} & {$[0.02]$} & {$[0.03]$} & {$[0.03]$} \\
\hline \multirow[t]{2}{*}{$\mathbf{U}_{\mathrm{S}, \text { crisis }}$} & 274.61 & 254.6 & 16.57 & 183.61 \\
\hline & [191.90] & {$[237.68]$} & [173.24] & [287.03] \\
\hline \multirow[t]{2}{*}{$\mathbf{k}_{\mathrm{a}, \mathrm{S}}$, crisis } & -0.8 & -0.86 & 1.71 & -1.15 \\
\hline & {$[0.87]$} & {$[0.92]$} & {$[3.74]$} & {$[1.44]$} \\
\hline \multirow[t]{2}{*}{$\mathbf{k}_{\mathbf{l}, \mathrm{S}, \text { crisis }}$} & 0.79 & 0.86 & -1.87 & 1.17 \\
\hline & {$[0.93]$} & [0.99] & {$[4.10]$} & {$[1.58]$} \\
\hline \multirow[t]{2}{*}{$\mathbf{k}_{\mathrm{FX}, \mathrm{S} \text {, crisis }}$} & $-0.05 * *$ & $-0.05 * *$ & 0.36 & 0.02 \\
\hline & {$[0.03]$} & {$[0.03]$} & {$[0.84]$} & {$[0.07]$} \\
\hline \multirow[t]{2}{*}{$\mathbf{U}_{\mathbf{L}}$} & $2,705.93 * * *$ & $3,696.82 * * *$ & $1,044.42$ & 996.09 \\
\hline & [933.20] & {$[1,123.16]$} & {$[1,238.43]$} & {$[1,447.91]$} \\
\hline \multirow[t]{2}{*}{$\mathbf{k}_{\mathrm{a}, \mathbf{L}}$} & $1.16^{* * *}$ & $1.04 * * *$ & $5.71 * *$ & 1.02 \\
\hline & {$[0.34]$} & {$[0.36]$} & {$[2.90]$} & {$[0.66]$} \\
\hline \multirow[t]{2}{*}{$\mathbf{k}_{\mathbf{l}, \mathbf{L}}$} & $-1.11 * * *$ & $-0.99 * *$ & $-6.08^{*}$ & -0.89 \\
\hline & {$[0.40]$} & {$[0.41]$} & {$[3.15]$} & {$[0.77]$} \\
\hline \multirow[t]{2}{*}{$\mathbf{k}_{\mathbf{F X}, \mathbf{L}}$} & -0.04 & -0.09 & 0.09 & -0.05 \\
\hline & {$[0.11]$} & {$[0.12]$} & {$[0.29]$} & {$[0.20]$} \\
\hline \multirow[t]{2}{*}{$\mathbf{U}_{\mathbf{L}, \text { crisis }}$} & $2,863.95$ & $15,019.41 * * *$ & $1,841.75$ & $4,952.50$ \\
\hline & {$[3,008.79]$} & {$[5,024.89]$} & {$[2,213.29]$} & {$[4,087.37]$} \\
\hline \multirow[t]{2}{*}{$\mathbf{k}_{\mathrm{a}, \mathbf{L}, \text { crisis }}$} & $2.41 *$ & 0.92 & -0.04 & $4.10^{*}$ \\
\hline & {$[1.35]$} & {$[1.47]$} & [11.33] & {$[2.20]$} \\
\hline \multirow[t]{2}{*}{$\mathbf{k}_{\mathbf{l}, \mathbf{L}, \text { crisis }}$} & $-2.69 *$ & -1.48 & -0.09 & $-4.84 *$ \\
\hline & {$[1.56]$} & {$[1.66]$} & [12.12] & {$[2.60]$} \\
\hline \multirow[t]{2}{*}{$\mathbf{k}_{\mathrm{FX}, \mathbf{L}, \text { crisis }}$} & -0.23 & $-0.51^{*}$ & -0.43 & $1.06^{*}$ \\
\hline & {$[0.26]$} & {$[0.28]$} & {$[0.96]$} & {$[0.55]$} \\
\hline Observations & 507 & 445 & 62 & 170 \\
\hline Wald test & 1319 & 1234 & 175 & 432 \\
\hline
\end{tabular}


covering 1997 to 2006 and 24 large-bank and 38 small-bank observations in the subsample covering 1988 to 1996 . The restriction in the number of observations in the sample covering 1988 to 1996 makes interpretation of results difficult in this subsample.

Differences in regulation and institutional structure of the ISE in the two periods (19881996 and 1997-2006) affect the analysis. Market value of net worth is the measure of "true" economic value. Markets must price stocks efficiently for market value of net worth to reflect true economic value. The Turkish stock market is relatively young; it started operations in 1986. Balaban and Kunter (1997) and Antoniou et al. (1997) find inefficiencies in the ISE using data from 1988 to 1995. Furthermore, Antoniou et al. (1997) show that following institutional and regulatory changes, the ISE becomes more efficient in the latter part of their sample period. This is why one must be cautious in interpreting estimates of SMVAM in the subsample covering years from 1988 to 1996.

Equation 3 disaggregates the market value of net worth into its bookable and unbookable components. Mark-up ratios for assets, liabilities and foreign-currency-related derivative transactions $\left(\mathrm{k}_{\mathrm{a}}, \mathrm{k}_{\mathrm{l}}\right.$, and $\left.\mathrm{k}_{\mathrm{FX}}\right)$ measure how investors mark up or down the value of these booked items. As expected, asset and liability mark-up ratios prove positive and negative, respectively, in all subsamples and bank groups except one. Asset mark-up ratio of small banks in non-crisis periods for the subsample covering the years 1988 to 2006 prove negative and insignificant. The small sample size and problems of market efficiency might explain the contradictory mark-up ratios in this subsample.

Markets capitalize one YTL of small-bank asset or liability at more than its book value in non-crisis periods and less than its book value in crisis periods. Results support the hypothesis that economic crisis forces revelation of adverse information about small banks. Consequently, investors mark-down the prices of small-bank assets and liabilities.

Markets judge one YTL of large-bank asset or liability at more than its book value in both non-crisis and crisis periods. In contrast to small banks, security prices of large banks are not depressed in times of crisis. Large banks may be less likely to hide adverse information and consequently security prices may be less likely to be depressed. An alternative explanation is that large banks are more skillful in hiding adverse information about their securities in both crisis and non-crisis periods. Investors may also believe large banks to be beneficiaries of Too-Big-To-Fail policies and do not mark-down large-bank assets and liabilities.

The significance of mark-up ratios for foreign-exchange-related derivative transactions indicates that investors take into account the foreign-currency exposure when pricing banks. Negative mark-up ratios indicates short-positions in foreign currencies for large banks. However, these positions are significant only in the 1999 and 2001 crisis-periods. In contrast to large banks, small banks have positive and significant mark-up ratios in noncrisis periods indicating long-positions in foreign currencies in the full sample and the sample covering 1997 to 2006.

\subsection{Transparency of financial statements}

The significance of hidden capital for large banks in crisis and non-crisis periods and for small banks in non-crisis periods indicates that unbookable components of net worth are important. Hypothesis 1 holds that financial statements are transparent. If financial statements are transparent, there should be no hidden capital and markup ratios should equal unity. Panel A of Table 4 reports the results for tests of transparency that uses the full sample, the subsample covering quarters from 1997 to 2006, the subsample covering years from 1988 to 1996, and the subsample covering year-end data from 1988 to 2006 . 
Financial statements of small and large banks prove opaque in non-crisis periods. In crisis periods, I fail to reject the hypothesis of transparent statements for small banks in all samples and for large banks in the subsample covering 1988 to 1996. Revelation of adverse information in times financial crisis, forces transparency in small-bank statements. The significance of hidden capital in both crisis $\left(\mathrm{U}_{\mathrm{L}}\right)$ and non-crisis periods $\left(\mathrm{U}_{\mathrm{L}}+\mathrm{U}_{\mathrm{L} \text {,crisis }}\right)$ explains why large bank financial statements prove opaque in crisis and non-crisis periods.

A heavier reliance on implicit and explicit safety nets in crisis periods relative to noncrisis periods may explain the significance of hidden capital. Management (or large shareholders who control management) may spread financial disinformation in order to increase and protect opportunistic benefits at the expense of other stakeholders. In times of crisis, all stakeholders learn of previously-concealed depletion in shareholder-contributed capital. This revelation necessitates new infusions of shareholder-capital or an increased reliance on the safety nets afforded by regulators.

Panel B of Table 4 investigates Hypothesis 2 which holds that banks need no new infusions of capital in crisis periods either from government or from shareholders. Alternative hypotheses maintain that banks may raise capital from shareholders and/or increase their reliance on government guarantees. Governments may contribute significant

Table 4 Tests of hypotheses. Panels A through C report p-values and $\chi 2$ statistics for tests of Hypothesis 1 through 3, respectively. Panel A tests the hypothesis of transparent statements for small and large banks in non-crisis and crisis periods (In non-crisis periods: $U_{k}=0$ and $k_{a, k}=1$ and $k_{1, k}=-1$. In crisis periods: $\mathrm{U}_{\mathrm{k}}+\mathrm{U}_{\mathrm{k}, \text { crisis }}=0$ and $\mathrm{k}_{\mathrm{a}, \mathrm{k}}+\mathrm{k}_{\mathrm{a}, \mathrm{k}, \text { crisis }}=1$ and $\mathrm{k}_{\mathrm{l}, \mathrm{k}}+\mathrm{k}_{\mathrm{l}, \mathrm{k}, \text { crisis }}=-1$ where $\mathrm{k}$ : $\mathrm{L}, \mathrm{S}$. The subscripts " $\mathrm{L}$, "S" stand for large and small banks). Panel B tests whether the magnitude of hidden capital differs in crisis and non-crisis periods $\left(\mathrm{U}_{\mathrm{k}}=\mathrm{U}_{\mathrm{k} \text {,crisis }}\right.$ where $\mathrm{k}$ : L, S.). Panel C tests whether SMVAM estimates of small and large banks $\operatorname{differ}\left(\mathrm{U}_{\mathrm{S}}=\mathrm{U}_{\mathrm{L}}, \mathrm{k}_{\mathrm{a}, \mathrm{S}}=\mathrm{k}_{\mathrm{a}, \mathrm{L}}\right.$ and $\mathrm{k}_{1, \mathrm{~S}}=\mathrm{k}_{1, \mathrm{~L}}$ in non-crisis periods. $\mathrm{U}_{\mathrm{S}}+\mathrm{U}_{\mathrm{S} \text {, crisis }}=\mathrm{U}_{\mathrm{L}}+\mathrm{U}_{\mathrm{L}, \text { crisis }}$, $\mathrm{k}_{\mathrm{a}, \mathrm{S}}+\mathrm{k}_{\mathrm{a}, \mathrm{S} \text {, crisis }}=\mathrm{k}_{\mathrm{a}, \mathrm{L}}+\mathrm{k}_{\mathrm{a}, \mathrm{L} \text {,crisis }}$ and $\mathrm{k}_{1, \mathrm{~S}}+\mathrm{k}_{1, \mathrm{~S} \text {, crisis }}=\mathrm{k}_{1, \mathrm{~L}}+\mathrm{k}_{1, \mathrm{~L} \text {,crisis }}$ in crisis periods.). SMVAM estimates are from Table 3. The first two columns report results for the full sample; the next two columns for the subsample from 1997 to 2006; the next two columns for the subsample from 1988 to 1996; the next two columns for end-of-year data from 1988 to 2006

\begin{tabular}{|c|c|c|c|}
\hline Full sample & 1997-2006 & 1988-1996 & Annual data \\
\hline $\begin{array}{ll}\text { P- } & \chi^{2} \\
\text { value } & \text { statistic }\end{array}$ & $\begin{array}{ll}\mathrm{P}- & \chi^{2} \\
\text { value } & \text { statistic }\end{array}$ & $\begin{array}{ll}\text { P- } & \chi^{2} \\
\text { value } & \text { statistic }\end{array}$ & $\begin{array}{ll}\mathrm{P}- & \chi^{2} \\
\text { value } & \text { statistic }\end{array}$ \\
\hline
\end{tabular}

\begin{tabular}{|c|c|c|c|c|c|c|c|c|}
\hline \multicolumn{9}{|c|}{ Panel A - Hypothesis 1 : Tests of transparency } \\
\hline Small banks in non-crisis periods & 0.00 & 47.44 & 0.00 & 45.51 & 0.00 & 32.99 & 0.00 & 17.53 \\
\hline Small banks in crisis periods & 0.79 & 1.05 & 0.78 & 1.10 & 0.64 & 1.69 & 0.99 & 0.12 \\
\hline Large banks in non-crisis periods & 0.00 & 40.46 & 0.00 & 40.78 & 0.00 & 15.83 & 0.01 & 11.68 \\
\hline Large banks in crisis periods & 0.00 & 35.46 & 0.00 & 45.73 & 0.13 & 5.69 & 0.02 & 10.03 \\
\hline \multicolumn{9}{|c|}{ Panel B - Hypothesis 2 : Estimates of hidden capital equal in crisis and non-crisis periods } \\
\hline Hidden capital of small banks & 0.00 & 47.44 & 0.00 & 45.51 & 0.00 & 32.99 & 0.00 & 17.53 \\
\hline Hidden capital of large banks & 0.79 & 1.05 & 0.78 & 1.10 & 0.64 & 1.69 & 0.99 & 0.12 \\
\hline \multicolumn{9}{|c|}{$\begin{array}{l}\text { Panel } C \text { - Hypothesis } 3 \text { : Estimates of hidden capital and mark-up ratios equal for small and large } \\
\text { banks }\end{array}$} \\
\hline Hidden capital in non-crisis periods & 0.00 & 10.35 & 0.00 & 12.98 & 0.44 & 0.59 & 0.42 & 0.65 \\
\hline Hidden capital in crisis periods & 0.05 & 3.82 & 0.00 & 14.74 & 0.13 & 2.28 & 0.12 & 2.40 \\
\hline $\begin{array}{l}\text { Asset and liability mark-up ratios in } \\
\text { non-crisis periods }\end{array}$ & 0.41 & 1.81 & 0.18 & 3.44 & 0.07 & 5.39 & 0.67 & 0.81 \\
\hline $\begin{array}{l}\text { Asset and liability mark-up ratios in } \\
\text { crisis periods }\end{array}$ & 0.14 & 3.94 & 0.30 & 2.43 & 0.07 & 5.29 & 0.14 & 3.94 \\
\hline
\end{tabular}


amounts of capital through implicit and explicit guarantees when shareholder-contributed capital erodes. Government guarantees would not show up in financial statements but would in unbookable assets, which are a component of hidden capital. If creditors rely on government-contributed capital to increase in value when and if banks are threatened with insolvency, I would expect that estimates of hidden capital would prove higher in crisis periods relative to non-crisis periods.

Panel B of Table 4 reports $\chi^{2}$-statistics and p-values for the test of difference in hidden capital estimates in crisis and non-crisis periods. Hidden capital estimates for large and small banks in crisis and non-crisis periods come from Table 3. Estimates of hidden capital in crisis periods prove larger than estimates in non-crisis periods for both small and large banks. Panel B shows that this difference is statistically significant for large banks in the subsample covering 1997 to 2006.

Reregulation of the coverage of deposit insurance supports the hypothesis that government guarantees become more important when banks are in trouble. Full-depositinsurance was instated following the 1994 and 2001 crises. Regulators tried to avert and/or dampen the effects of the crises. Regulators explicitly increased the guarantees that banks enjoyed at the exact time when infusions of capital were needed.

Table 5 investigates whether banks raise capital from shareholders more in crisis periods relative to non-crisis periods. I collect annual data on paid-in capital for the period of 1991 to 2006 from the The Banks Association of Turkey and increases in capital from rights issues for the whole sample period from the ISE. ${ }^{17}$ Table 5 reports the means, the t-statistics and p-values for the tests of differences in means for paid-in capital, increases in paid-in capital and increases in capital from rights issues. Unfortunately, the ISE provides data on surviving banks only. There is, therefore, survivorship bias in the sample. The banks excluded went bankrupt precisely due to the depletion in their capital base and their inability to raise additional funds from shareholders. As such, the banks in the sample of rights issues are the ones who are more likely to have raised capital from their shareholders.

Table 5 shows that paid-in capital decreases in crisis periods for both small and large banks. Results indicate that shareholders provide more capital in crisis periods since increases in paid-in capital and capital from rights issues prove higher in crisis periods than in non-crisis periods. However, the changes in both the level and flow of paid-in capital prove statistically insignificant. The survivorship bias in the rights issues sample indicates a narrower difference between capital raised in crisis and non-crisis periods. To sum up, the results provide no conclusive evidence that banks raise capital from shareholders to offset decreases in net worth in times of crisis.

\subsection{Impact of size on transparency and bank operations}

Large and small banks may operate and book their operations in fundamentally different ways (DeYoung et al. 2004; Berger et al. 2004). DeYoung et al. (2004) describe how deregulation and technological change reshaped the competitive environment for small and large banks in the US. The authors develop a simple model in which small and large banks differentiate unit costs and product mix to compete. The last two decades saw a similar

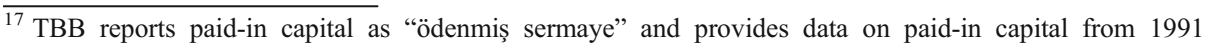
onwards. Data on increases in capital from rights issues is available from Istanbul Stock Exchange at http:// www.imkb.gov.tr/sirket/sermaye temettu.htm. Increases in capital from rights issues is the sum of increases in capital from exercised pre-emptive rights and rights restricted to shareholders. Exercised pre-emptive rights and rights restricted to shareholders are respectively, "rüçhan hakkı kullandırılan bedelli artırımlar" and "rüçhan hakkı kısıtlanan bedelli artırımlar".
} 
Table 5 Sources of capital in crisis periods. Table tests whether banks raise capital from shareholders more in crisis periods than in non-crisis periods. The Banks Association of Turkey provides data on paid-in capital from 1991 to 2006. ISE provides data on increases in capital from rights issues. Values are in December2006 million YTL

Funds from shareholders in crisis and non-crisis periods

\begin{tabular}{llrrrr}
\hline & & $\begin{array}{l}\text { Non-crisis } \\
\text { periods }\end{array}$ & $\begin{array}{l}\text { Crisis } \\
\text { periods }\end{array}$ & T-stat & P-value \\
\hline Small banks & Paid-in capital & 214 & 156 & 1.69 & 0.09 \\
& Increase in paid-in capital & 73 & 97 & -1.16 & 0.25 \\
& Increase in capital from rights issues & 42 & 56 & -1.18 & 0.25 \\
\multirow{2}{*}{ Large banks } & 1,084 & 862 & 1.31 & 0.20 \\
& Paid-in capital & 348 & 477 & -1.21 & 0.24 \\
& Increase in paid-in capital & 214 & 326 & -1.28 & 0.22 \\
\hline
\end{tabular}

change in the Turkish competitive environment induced by deregulation and technological change. This is why I control for bank size in estimating SMVAM.

Panel $\mathrm{C}$ of Table 4 investigates Hypothesis 3 which holds that small and large banks operate and book their operations in similar ways. Panel $\mathrm{C}$ reports $\chi^{2}$-statistics and p-values for the test of equality in hidden capital and mark-up ratios for small and large banks. In the full sample and the subsample covering quarters from 1997 to 2006, large- and small-bank hidden capital is significantly different. According to Kane (2001) Too-Big-To-Fail policies enable creditors to depend on the government to rescue large financial institutions when and if they run into trouble. The findings suggest that markets perceive the four-large banks to be benefiting from Too-Big-To-Fail policies. Panel $\mathrm{C}$ reports no significant difference between the mark-up ratios of small and large banks. Findings indicate that small and large banks record bookable assets and liabilities in similar ways. The differences between small and large banks lie not in how they report their operations but in how regulators treat them. As put forth by the Too-Big-To-Fail hypothesis, large banks enjoy credit enhancements afforded by the Turkish government.

\subsection{Mergers and changes in reporting standards}

Reregulation in reporting standards and mergers may also affect the findings. First, banks adopted new accounting measures to accommodate the effects of high inflation in 2001 . Financial statements from the fourth quarter of 2001 to the third quarter of 2002 used these new measures. Second, the latter part of the sample period is marked by restructuring. Table 1 shows that sixteen banks proposed eleven merger bids in the sample period. Nine of the eleven bids took place from 2004 to 2006. Merger transactions may change operations and reporting practices (Cornett et al. 2006). This is why mergers may affect transparency of financial statements. This section discusses whether and how mergers and changes in regulation affect the analysis.

I interpreted the time-variation in estimates of hidden capital as evidence of the importance of government-provided capital in crisis periods. The change in accounting measures may also explain the higher hidden capital estimates in crisis periods if inflation accounting increases opaqueness. This does not seem to be the case since the stated purpose of the change in accounting standards was to make financial statements more transparent. 
Table 6 Estimates of Statistical Market Value Accounting Model with controls for merger activity. The following system of equations is estimated using Feasible Generalized Least Squares (FGLS): $\mathrm{MV}_{\mathrm{k}, \mathrm{it}}=\alpha_{\text {merger }} * \mathrm{M}_{\mathrm{it}}+\mathrm{U}_{\mathrm{k}}+$ $\mathrm{k}_{\mathrm{a}, \mathrm{k}} * \mathrm{~A}_{\mathrm{k}, \mathrm{it}}+\mathrm{k}_{\mathrm{l}, \mathrm{k}} * \mathrm{~L}_{\mathrm{k}, \mathrm{it}}+\mathrm{k}_{\mathrm{FX}, \mathrm{k}} * \mathrm{FX}_{\mathrm{k}, \mathrm{it}}+\mathrm{U}_{\mathrm{k}, \text { crisis }}+\mathrm{k}_{\mathrm{a}, \mathrm{k} \text {, crisis }} * \mathrm{~A}_{\mathrm{k}, \mathrm{it}} * \mathrm{I}_{\text {crisis }}+\mathrm{k}_{\mathrm{l}, \mathrm{k}, \text { crisis }} * \mathrm{~L}_{\mathrm{k}, \mathrm{it}} * \mathrm{I}_{\text {crisis }}+\mathrm{k}_{\mathrm{FX}, \mathrm{k}, \text { crisis }} *$ $\mathrm{FX}_{\mathrm{k}, \mathrm{it}} * \mathrm{I}_{\text {crisis }}+\mathrm{e}_{\mathrm{k}, \mathrm{it}}$, where $\mathrm{k}$ : L, S. The subscripts " $\mathrm{L}$ " and " $\mathrm{S}$ " stand for large and small banks. MV is market value of net worth. $\mathrm{M}$ is an indicator taking on the value 1 if bank i receives a merger bid in period $\mathrm{t}$ and 0 otherwise. A and L are book values of assets and liabilities. FX is book value of off-balance-sheet foreigncurrency-related derivative contracts. $U$ stands for hidden capital; $k_{a}, k_{1}$ and $k_{f X}$ stand for mark-up ratios of assets, liabilities and FX, respectively. $\mathrm{I}_{\text {crisis }}$ is an indicator for crisis years. Values are in December-2006 million YTL. First column of table reports results estimated on the full sample, the second column on the subsample from 1997 to 2006, the third column on the subsample from 1988 to 1996, and the fourth column on the subsample which covers the end-of-year data from 1988 to 2006. Absolute values of standard errors are in brackets. Significance levels are shown as *, ** and $* * *$, representing $10 \%, 5 \%$, and $1 \%$ significance

\begin{tabular}{|c|c|c|c|c|}
\hline & Full sample & 1997-2006 & 1988-1996 & Annual Data \\
\hline \multirow[t]{2}{*}{$\alpha_{\text {merger }}$} & $834.40 * * *$ & $878.85 * * *$ & -201.5 & $667.80^{* *}$ \\
\hline & {$[142.00]$} & [151.77] & [179.59] & [265.84] \\
\hline \multirow[t]{2}{*}{$\mathbf{U}_{\mathrm{S}}$} & $-327.51 * * *$ & $-387.10 * * *$ & 104.47 & $-204.80^{*}$ \\
\hline & {$[66.35]$} & {$[75.10]$} & {$[68.15]$} & [113.15] \\
\hline \multirow[t]{2}{*}{$\mathbf{k}_{\mathrm{a}, \mathrm{s}}$} & $1.10^{* * *}$ & $1.17^{* * *}$ & $-1.26^{*}$ & $1.49^{* * *}$ \\
\hline & {$[0.30]$} & {$[0.32]$} & {$[0.64]$} & {$[0.56]$} \\
\hline \multirow[t]{2}{*}{$\mathbf{k}_{1, \mathrm{~s}}$} & $-1.02 * * *$ & $-1.09 * * *$ & $1.46^{* *}$ & $-1.44 * *$ \\
\hline & {$[0.33]$} & {$[0.35]$} & [0.69] & {$[0.62]$} \\
\hline \multirow[t]{2}{*}{$\mathbf{k}_{\mathbf{F X}, \mathbf{S}}$} & $0.05^{* * *}$ & $0.06^{* * *}$ & -0.04 & $0.05^{*}$ \\
\hline & {$[0.02]$} & {$[0.02]$} & {$[0.03]$} & {$[0.03]$} \\
\hline \multirow[t]{2}{*}{$\mathbf{U}_{\mathrm{S}, \text { crisis }}$} & 297.41 & 281.49 & 3.18 & 217.24 \\
\hline & [182.71] & [225.12] & [170.85] & [281.28] \\
\hline \multirow[t]{2}{*}{$\mathbf{k}_{\mathrm{a}, \mathrm{S}}$, crisis } & -0.58 & -0.63 & 1.79 & -0.84 \\
\hline & {$[0.83]$} & {$[0.87]$} & {$[3.68]$} & {$[1.42]$} \\
\hline \multirow[t]{2}{*}{$\mathbf{k}_{\mathrm{l}, \mathrm{S}}$, crisis } & 0.56 & 0.63 & -1.94 & 0.83 \\
\hline & {$[0.89]$} & {$[0.94]$} & [4.03] & {$[1.55]$} \\
\hline \multirow[t]{2}{*}{$\mathbf{k}_{\mathbf{F X}, \mathbf{S}, \text { crisis }}$} & $-0.05 * *$ & $-0.06^{* *}$ & 0.36 & 0.02 \\
\hline & {$[0.02]$} & {$[0.03]$} & {$[0.83]$} & {$[0.07]$} \\
\hline \multirow[t]{2}{*}{$\mathbf{U}_{\mathbf{L}}$} & $2,750.87 * * *$ & $3,740.54 * * *$ & 1044.42 & 1026.05 \\
\hline & [931.97] & {$[1,121.63]$} & {$[1,238.43]$} & {$[1,445.43]$} \\
\hline \multirow[t]{2}{*}{$\mathbf{k}_{\mathrm{a}, \mathrm{L}}$} & $1.18^{* * *}$ & $1.07 * * *$ & $5.71 * *$ & 1.05 \\
\hline & {$[0.34]$} & {$[0.36]$} & {$[2.90]$} & {$[0.66]$} \\
\hline \multirow[t]{2}{*}{$\mathbf{k}_{\mathbf{l}, \mathbf{L}}$} & $-1.14 * * *$ & $-1.02 * *$ & $-6.08^{*}$ & -0.92 \\
\hline & {$[0.40]$} & {$[0.41]$} & [3.15] & {$[0.77]$} \\
\hline \multirow[t]{2}{*}{$\mathbf{k}_{\mathbf{F X}, \mathbf{L}}$} & -0.05 & -0.09 & 0.09 & -0.05 \\
\hline & {$[0.11]$} & {$[0.12]$} & {$[0.29]$} & {$[0.20]$} \\
\hline \multirow[t]{2}{*}{$\mathbf{U}_{\mathbf{L}, \text { crisis }}$} & 2819.01 & $14,975.69^{* * *}$ & 1841.75 & 4922.54 \\
\hline & {$[3,004.72]$} & {$[5,017.94]$} & {$[2,213.29]$} & {$[4,080.23]$} \\
\hline \multirow[t]{2}{*}{$\mathbf{k}_{\mathrm{a}, \mathrm{L}}$, crisis } & $2.39 *$ & 0.9 & -0.04 & $4.08^{*}$ \\
\hline & {$[1.35]$} & {$[1.47]$} & [11.33] & {$[2.20]$} \\
\hline \multirow[t]{2}{*}{$\mathbf{k}_{\mathbf{l}, \mathbf{L}, \text { crisis }}$} & $-2.66^{*}$ & -1.46 & -0.09 & $-4.81 *$ \\
\hline & {$[1.55]$} & {$[1.66]$} & {$[12.12]$} & [2.59] \\
\hline \multirow[t]{2}{*}{$\mathbf{k}_{\mathbf{F X}, \mathrm{L}, \text { crisis }}$} & -0.22 & $-0.51 *$ & -0.43 & $1.06^{*}$ \\
\hline & {$[0.26]$} & {$[0.28]$} & {$[0.96]$} & {$[0.55]$} \\
\hline
\end{tabular}


Table 6 (continued)

\begin{tabular}{lcccc}
\hline & Full sample & 1997-2006 & 1988-1996 & Annual Data \\
\hline Observations & 507 & 445 & 62 & 170 \\
Wald test & 1437 & 1351 & 180 & 451 \\
\hline
\end{tabular}

However, I have no way of testing for the stand-alone effect of the change in accounting standards.

Table 6 investigates whether and how mergers change results using an indicator (named merger indicator) that takes on the value one if the bank receives or proposes a merger bid in the year and zero otherwise. The coefficient for merger indicator is positive and significant in all samples except the subsample that covers the years from 1988 to 1996. The small number of observations in which the indicator is one (there is only one announcement of a merger bid) may explain why the coefficient proves insignificant in this subsample. Results indicate that investors judge mergers to be value enhancing. Including the merger indicator does not qualitatively change the SMVAM estimates.

\section{Conclusion}

The Statistical Market Value Accounting Model disaggregates the ways in which accounting values of net worth fail to accord with stock market estimates of the "true economic value". Because the Turkish economy experienced high volatility and deregulation in the last two decades, Turkish commercial banks provide an ideal setting in which to study transparency and explore sources of hidden capital.

Statements of sample banks prove opaque. One source of opacity is hidden capital. Hidden capital increases in periods of crisis. I conjecture that the main component of hidden capital is government-contributed capital, which increases in value in times of crisis. Crisis necessitates infusions of capital. Banks may raise capital either from shareholders or from government in the form of heavier reliance on implicit and explicit safety nets. Results indicate that government-provided capital gains importance in crisis periods whereas there is no significant evidence of capital-raising from shareholders.

Hidden capital is significantly more important for large banks than it does for small banks. It is possible that large banks with their concentration in foreign-currency-related contracts were in a vulnerable position and stood to benefit more from governmentcontributed capital. If this is the case, large banks benefited from Too-Big-To-Fail policies. Investors may also have judged the Turkish government to have insufficient capital to rescue all insolvent institutions. In the sample period, TMSF closed five of the small banks and none of the large banks. With capital constraints, the Turkish government might have preferred to keep the largest banks afloat and promptly close the insolvent small banks.

Within the unique setting of the Turkish experience, possible sources of hidden capital include off-balance-sheet transactions that pose significant risk (such as foreign-exchange risk), and explicit and implicit forms of safety nets. Borrowers, depositors, regulators, banks and taxpayers need to pay close attention to transparency when they evaluate each other's performance.

Regulators in many developing and developed countries responded to the challenges posed by the sub-prime mortgage crisis by increasing the maximum level of deposit- 
insurance coverage ${ }^{18}$. Findings of this paper indicate that increasing insurance coverage in times of crisis allows banks to rely on government-contributed capital instead of shareholder-contributed capital. Relying on government contributed capital introduces moral hazard problems and decreases the transparency financial statements. To combat the problems of moral hazard, regulators and taxpayers need to identify the consequences of distorted incentives. However, deposit insurance, that gives rise to moral hazard problems, also decreases transparency of financial statements. This is why we, the taxpayers, and the regulators need to be vigilant to ensure that the opaqueness in financial statements does not hide the consequences of distorted incentives.

Acknowledgements The author would like to express her gratitude to Edward Kane for his guidance and mentoring. The author would also like to thank Haluk Ünal, the anonymous referee, and Hassan Tehranian for their insightful suggestions that helped improve the paper.

\section{References}

Alparslan M, Tulay B, Erdonmez PA (2000) "Mevduat Sigorta Sisteminin Çeşitli Ülkelerde ve Türkiye”de Uygulanması", The Banks Association of Turkey. Available at: http://www.tbb.org.tr/turkce/arastirmalar/ sigorta.zip

Alper CE, Öniş Z (2003) Financial globalization, the democratic deficit, and recurrent crises in emerging markets: the turkish experience in the aftermath of capital account liberalization. Emerging Markets Finance and Trade 39:5-26

Antoniou A, Ergul N, Holmes P (1997) Market Efficiency, Thin Trading and Non-linear Behavior: Evidence from an Emerging Market. European Financial Management 3:175-190

Balaban E, Kunter K (1997) A note on the efficiency of financial markets in a developing country. Applied Economic Letters 4:109-112

Baum C (2006) An introduction to modern econometrics using STATA. STATA, College Station

Berg A (1999) “The Asia Crisis Causes, Policy Responses, and Outcomes”, IMF Working Paper No. 99/138. Available at SSRN: http://ssrn.com/abstract $=880665$

Berger AN, Demirgüç-Kunt A, Levine R, Haubrich JG (2004) Bank concentration and competition: an evolution in the making. Journal of Money, Credit and Banking 36:433-451

The Banks Association of Turkey (1998) 40. Yılında Türkiye Bankacılar Birliği ve Türk Bankacılık Sistemi. Available at: http://www.tbb.org.tr/turkce/YENI_40yil.htm.

The Banks Association of Turkey (2001) "Son Dönemde Bankacılık Alanında Gerçekleștirilen Yasal ve Düzenliyici Değisiklikler, 1999-2001”. Available at www.tbb.org.tr/turkce/dergi/dergi39/Düzenleme. doc.

Cornett MM, McNutt JJ, Tehranian H (2006) Performance changes around bank mergers: revenue enhancements versus cost reductions. Journal of Money Credit and Banking 38:1013-1050

Damar E (2004) "The Turkish Banking Sector in the 1980s, 1990s and Beyond" Tacoma. Department of Economics, Pacific Lutheran University, Unpublished Manuscript, WA

Danielsson Jon, Saltoğlu Burak (2003) "Anatomy of a Market Crash: A Market Microstructure Analysis of the Turkish Overnight Liquidity Crisis”, EFA 2003 Annual Conference Paper No. 965. Available at SSRN: http://ssrn.com/abstract $=424924$

DeYoung R, Hunter RC, Udell GF (2004) The past, present, and probable future for community banks. Journal of Financial Services Research 25:85-133

Grossman RS (1992) Deposit insurance, regulation, and moral hazard in the thrift industry: evidence from the 1930's. American Economic Review 82(4):800-821

Institute of International Finance (2009) “Capital Flows to Emerging Market Economies", available at: http:// www.iif.com.

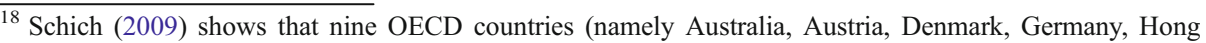
Kong, Iceland, Ireland, Singapore, Slovak Republic) instituted unlimited deposit insurance and sixteen OECD countries expanded deposit insurance coverage.
} 
Jang Ji-Hyang (2005) “Taming Political Islamists by Islamic Capital: The Passions and the Interests in Turkish Islamic Society”, Ph.D. Dissertation, University of Texas at Austin. Available at: http://www.lib. utexas.edu/etd/d/2005/jangj05548/jangj05548.pdf

Jensen MC, Meckling WH (1976) Theory of the firm: Managerial behavior, agency costs, and ownership structure. Journal of Financial Economics 3:305-360

Kane EJ (1989) Changing incentives facing financial-services regulators. Journal of Financial Services Research 2:265-274

Kane EJ (1997) Ethical foundations of financial regulation. Journal of Financial Services Research 12:51-74

Kane EJ (2000) Capital movements, banking insolvency, and silent runs in the Asian financial crisis. PacificBasin Finance Journal 8:153-175

Kane EJ (2001) Dynamic inconsistency of capital forbearance: Long-run vs. short-run effects of too-big-tofail policymaking. Pacific-Basin Finance Journal 9:281-299

Kane EJ (2004) Continuing dangers of disinformation in corporate accounting reports. Review of Financial Economics 13:149-164

Kane EJ, Ünal H (1990) Modeling structural and temporal variation in the market's valuation of banking firms. Journal of Finance 45:113-135

Kane EJ, Ünal H, Demirgüç-Kunt A (1991) “Capital Positions of Japanese Banks,” Pacific-Basin Capital Markets Research, Volume II, S.G. Rhee and R.P. Chang, eds., pp. 125-141. Amsterdam: Elsevier Science Publishers B.V.

Kane EJ, Wilson B (2002) Regression evidence of safety-net support in Canada, the UK and the U.S., 18931992. The Quarterly Review of Economics and Finance 16:1-23

Kibritcioglu Aykut (2001) 'Economic Crises and Governments in Turkey, 1969-2001 (Türkiye'de Ekonomik Krizler ve Hükümetler, 1969-2001)", Available at SSRN: http://ssrn.com/abstract=895806

Merton RC (1977) An analytic derivation of the cost of deposit insurance and loan guarantees. Journal of Banking and Finance 1:3-11

Milliyet Gazetesi, “Kara Çarşamba”. Available at: http://www.milliyet.com.tr/2001/02/22/ekonomi/eko01. html

Müslümov A (2005) Full deposit insurance and the moral hazard problem: The case of Turkish banking system. Boğaziçi Journal - Review of Social, Economic and Administrative Studies, 19:1-22.

O'Hara M, Shaw W (1990) Deposit insurance and wealth effects: the value of being "'Too Big To Fail". Journal of Finance 45:1587-1600

Önder Z, Özyildirim S (2008) Market reaction to risky banks: did generous deposit guarantee change it? World Development 36:1415-1435

Öniş Ziya, Caner Bakır (2007) “Turkey’s Political Economy in the Age of Financial Globalization: The Significance of the EU Anchor", South European Society \& Politics, 147 - 164.

Saunders A, Strock E, Travlos NG (1990) Ownership structure, deregulation, and bank risk taking. Journal of Finance 45:643-654

Schich S (2009) Challenges associated wity the expansion of deposit insurance coverage during fall 2008. Economics, The Open-access Open Assessment E-Journal 3:2009-20

Selçuk F, Ertuğrul A (2001) A brief Account of the Turkish economy: 1980-2000. Russian \& East European Finance and Trade 37:6-28

Soral HB, İșcan TB, Hebb G (2006) Fraud, banking crisis, and regulatory enforcement: evidence from microlevel transactions data. European Journal of Law and Economics 21:179-197

Press STATA (2005) STATA Base Reference Manual, Volume 1, Release 9. College Station, Texas

Vishwanath T, Kaufmann D (2001) Toward transparency: new approaches and their application to financial markets. The World Bank Research Observer 16:41-57

Ünal H, Demirgüç-Kunt A, Leung K (1993) The brady plan, 1989 debt-reduction agreement, and bank stock returns in united stated and japan. Journal of Money, Credit, and Banking 25:410-429

Wooldridge J (2002) Econometric Analysis of Cross Section and Panel Data, The MIT Press. 